\title{
Inactivation of Endothelial Derived Relaxing Factor by Oxidized Lipoproteins
}

Jane H. Chin, Salman Azhar, and Brian B. Hoffman

Department of Medicine, Stanford University School of Medicine and Geriatric Research, Education and Clinical Center, Veterans Affairs Medical Center, Palo Alto, California 94304

\begin{abstract}
Endothelial cell derived relaxing factor (EDRF) mediated relaxation of blood vessels is impaired in vessels exposed to lipoproteins in vitro and in arteries of hyperlipidemic humans and animals. To investigate the mechanism by which lipoproteins impair the effects of EDRF, which is likely nitric oxide (NO) or a related molecule, we have bioassayed EDRF/NO activity by measuring its ability to increase cGMP accumulation in rat fetal lung cultured fibroblasts (RFL-6 cells). Low density lipoprotein modified by oxidation (ox-LDL) induced a concentration-dependent inhibition of EDRF activity that had been released from bovine aortic endothelial cells (BAEC) stimulated with bradykinin or the calcium ionophore $\mathbf{A 2 3 1 8 7}$. In addition, lipoproteins directly impaired authentic NO-induced stimulation of cGMP accumulation in the detector cells; stimulation by sodium nitroprusside was unaffected. Ox-LDL or oxidized $\mathrm{HDL}_{3}$ were highly potent in blocking NO-stimulated cGMP accumulation with $\mathrm{EC}_{50}$ 's of $\sim 1 \mu \mathrm{g} / \mathrm{ml}$. Lipid extracted from ox-LDL blocked NO-stimulated cGMP accumulation to about the same extent as intact ox-LDL, while the protein component of ox-LDL did not inhibit the cGMP response. These results suggest that the lipid component of oxidized lipoproteins inactivate EDRF after its release from endothelial cells. (J. Clin. Invest. 1992. 89:10-18.) Key words: EDRF • nitric oxide • lipoproteins $\bullet$ bradykinin
\end{abstract}

\section{Introduction}

A variety of vasoactive agents indirectly relax vascular smooth muscle by activating receptors on endothelial cells. These vasodilators require an intact endothelium and function by promoting the release of a relaxing factor from the endothelium, termed endothelium derived relaxing factor $(E D R F)^{1}(1,2)$. EDRF has many properties similar to nitric oxide (NO) and may be NO itself or a NO-containing compound such as nitrosothiols (3). Vascular endothelial cells synthesize NO from the terminal guanidino nitrogen of L-arginine (4) and the formation of NO is blocked by $N^{\mathrm{G}}$-monomethyl-L-arginine, an inhibitor of L-arginine, by inhibition of the enzyme NO synthase (5).

Address correspondence to Brian B. Hoffman, M.D., VA Medical Center, 182B, 3801 Miranda Ave., Palo Alto, CA 94304. 1991.

Received for publication 8 May 1991 and in revised form 5 August

1. Abbreviations used in this paper: BAEC, bovine aortic endothelial cell; EDRF, endothelium derived relaxing factor; nLDL, native low density lipoprotein; NO, nitric oxide; ox-LDL, oxidized low density lipoprotein; RFL-6, rat fetal lung fibroblast; TBARS, thiobarbituric acid-reactive substance.

The Journal of Clinical Investigation, Inc.

Volume 89, January 1992, 10-18
However, there may be more than one EDRF (6). Endothelialdependent vasodilators increase endothelial cell cytoplasmic calcium concentrations which enhances the activity of the enzyme NO synthase leading to release of NO from the endothelial cells. NO, which has a very short half-life, rapidly diffuses to vascular smooth muscle where it activates guanylate cyclase, leading to an increase cGMP accumulation and smooth muscle relaxation (7).

EDRF influences vascular tone and blood pressure. However, the production of EDRF/NO is not limited to the endothelium and has been shown to be synthesized in various mammalian tissues including macrophages, neutrophils, Kupffer cells, adrenal tissue, and cerebellum (8). Consequently, the NO system is widespread and may be important both in signal transduction to link extracellular signals to the biosynthesis of the second messenger cGMP in target cells $(8,9)$ and in immunological reactions (10).

Several studies have shown that relaxation of vascular smooth muscle by endothelium-dependent vasodilators such as acetylcholine is inhibited by lipoproteins (11-15), especially $\mathrm{LDL}$, a risk factor for atherosclerosis (16). In addition, arteries and arterioles from cholesterol-fed animals $(17,18)$ and from humans with atherosclerosis or hypercholesterolemia (19-21) are relatively unresponsive to endothelium-dependent vasodilators. These results suggest that impaired EDRF action in hyperlipidemic or atherosclerotic individuals could contribute to augmented responses to vasoconstricters (22-24).

Oxidized LDL (ox-LDL), more potently than native LDL, markedly inhibited endothelium-dependent relaxation of rabbit aorta (13) and pig coronary artery $(23,24)$. In addition, ox-LDL has been shown to potentiate agonist-induced vasoconstriction by a direct effect on vascular smooth muscle (25). LDL modified by oxidation has cytotoxic and atherogenic properties $(16,26)$. Ox-LDL within the artery wall, especially in atherosclerotic plaques, may be the atherogenic form of LDL $(27,28)$. More recently, macrophage-derived foam cells from rabbit atherosclerotic lesions have been shown to promote oxidation of LDL (29). The mechanism by which oxLDL impairs endothelial cell-mediated smooth muscle relaxation is uncertain.

The present experiments were undertaken to determine whether the inhibitory effects of lipoproteins on EDRF could be detected in a simplified model using cultured bovine aortic endothelial cells (BAEC) as a source of EDRF. EDRF was assayed by its capacity to stimulate cGMP accumulation in a detector cell, rat fetal lung fibroblasts (RFL-6). We have compared the effects of native and oxidized lipoproteins on EDRF released from the BAEC upon stimulation by bradykinin or the calcium ionophore A23187 and subsequent transfer of conditioned medium from BAEC to the RFL- 6 detector cells. The cell culture system offers the distinct advantage of readily separating out lipoprotein effects on the donor cell from those in the detector cells. We found that ox-LDL markedly inactivated EDRF that had been released from the BAEC as well as inacti- 
vating exogenous authentic NO. This inhibitory effect was due mainly to the lipid component of ox-LDL.

\section{Methods}

Materials. Bradykinin acetate, catalase (from bovine liver), superoxide dismutase (from bovine liver), hypoxanthine, xanthine oxidase, indomethacin, butylated hydroxytoluene (BHT), 1,1,3,3-tetraethoxypropane, soybean trypsin inhibitor, 1-methyl-3-isobutyl xanthine (IBMX), 1- $\alpha$-lysophosphatidylcholine from egg yolk, 1- $\alpha$-phosphatidylcholine from egg yolk, 1- $\alpha$-phosphatidylcholine, diarachidoyl, and 1- $\alpha$-phosphatidylcholine, dilinoleoyl, ascorbic acid, ferrous sulfate (Sigma Chemical Co., St. Louis, MO); 2-thiobarbituric acid (Eastman Kodak Co., Rochester, NY); Hepes (Calbiochem-Behring Corp., La Jolla, CA); collagenase (CLS IV; Worthington Biochemicals, Freehold, NJ); BSA (fraction V, fatty acid free; Miles Laboratories Inc., Naperville, IL); elastase (EC134, Elastin, Pacific, MO); nitric oxide (Matheson Gas Products, Seacaucus, NJ); DMEM, F-12 Ham's nutrient mixture, L-glutamine, trypsin-EDTA (10X), antibiotic-antimycotic (100X) (Gibco, Grand Island, NY); FBS (Defined; HyClone Laboratories, Logan, UT).

Cell culture. To prepare BAEC in culture as a source of EDRF, bovine thoracic aortas were freshly obtained from a local slaughter house and placed in chilled Dulbecco's PBS (2.68 mM KCl, $1.47 \mathrm{mM}$ $\mathrm{KH}_{2} \mathrm{PO}_{4}, 136.9 \mathrm{mM} \mathrm{NaCl}$, and $8.06 \mathrm{mM} \mathrm{Na}_{2} \mathrm{HPO}_{4}$ ) supplemented with glucose $(2 \mathrm{~g} /$ liter $)$, penicillin $(100 \mathrm{U} / \mathrm{ml})$, streptomycin $(100 \mu \mathrm{g} /$ $\mathrm{ml})$, and amphotericin $\mathrm{B}(0.25 \mu \mathrm{g} / \mathrm{ml})$. Fat and connective tissues were removed and the aorta was cut into short segments and opened longitudinally under aseptic conditions. Endothelial cells were isolated by gently scraping the inner luminal surface of the aorta with a scalpel and digesting the scrapings for $15 \mathrm{~min}$ at room temperature in sterile medium consisting of DMEM, $10 \mathrm{mM}$ Hepes, collagenase $(1 \mathrm{mg} / \mathrm{ml}), B S A$ $(1 \mathrm{mg} / \mathrm{ml})$, soybean trypsin inhibitor $(0.5 \mathrm{mg} / \mathrm{ml})$, and elastase $(0.1$ $\mathrm{mg} / \mathrm{ml}$ ), adjusted to $\mathrm{pH}$ 7.4. The digestion was stopped by adding DMEM medium containing antibiotic, $10 \mathrm{mM}$ Hepes, and $10 \%$ FBS. Endothelial cells were collected by centrifugation for $10 \mathrm{~min}$ at $200 \mathrm{~g}$ at room temperature, and were washed twice in DMEM-Hepes buffer. The final cell pellets were resuspended in DMEM medium with $10 \%$ FBS and $1 \%$ antibiotics and plated in T-25 plastic tissue culture flasks and grown to confluence. The cells exhibited the "cobblestone pattern" typical of endothelial cells.

Rat fetal lung fibroblasts (RFL-6; American Type Culture Collection, Rockville, MD, and generous gift from Ruth Hwang, Abbott Laboratories, Chicago, IL) were cultured in F-12 Ham's nutrient mixture containing $15 \% \mathrm{FBS}$ and $4 \mathrm{mM}$ glutamine, penicillin $(100 \mathrm{U} / \mathrm{ml})$, streptomycin $(100 \mu \mathrm{g} / \mathrm{ml})$, and amphotericin B $(0.25 \mu \mathrm{g} / \mathrm{ml})$.

Cells were incubated at $37^{\circ} \mathrm{C}$ under an atmosphere of $95 \% \mathrm{O}_{2}-5 \%$ $\mathrm{CO}_{2}$. BAEC and RFL- 6 cells were subcultured by removing adherent cells with $0.05 \%$ trypsin and $0.02 \%$ EDTA. The harvested cells were plated into $100-\mathrm{mm}$ dishes or T-75 flasks for stock culture or $35-\mathrm{mm}$ dishes for lipoprotein experiments. Cells were counted by Coulter counter.

Preparation of authentic nitric oxide. Nitric oxide gas from a gas cylinder was collected in special designed gas-tight glass cylinder with stopcocks on both ends and fitted with a silicone rubber injection septum that allowed removal of nitric oxide by a syringe (30). $10 \mu \mathrm{l}$ of authentic nitric oxide gas was removed and added to another glass cylinder containing $100 \mathrm{ml}$ of cold distilled water previously deoxygenated by bubbling for at least $3 \mathrm{~h}$ with helium. Various volumes of the $0.01 \%$ (vol/vol) stock solution containing dissolved nitric oxide $(5,10$, 20,50 , or $100 \mu \mathrm{l}$ ) were added directly to RFL-6 cells to a final volume of $1 \mathrm{ml}$.

Preparation of lipoproteins. Human LDL and high density lipoproteins $\left(\mathrm{HDL}_{3}\right)$ were isolated by preparative ultracentrifugation from plasma of healthy male donors as previously described (31). The LDL fraction was isolated between densities of $1.02-1.05 \mathrm{~g} / \mathrm{ml}$ and the $\mathrm{HDL}_{3}$ fraction between 1.125 and $1.210 \mathrm{~g} / \mathrm{ml}$. To remove contaminat- ing plasma proteins, these fractions were recentrifuged for $18 \mathrm{~h}$ at the appropriate density and stored at $4^{\circ} \mathrm{C}$ in PBS containing $0.2 \mathrm{mM}$ EDTA to minimize oxidation. Prior to use in experiments, the purified lipoproteins were dialyzed at $4^{\circ} \mathrm{C}$ for $18-24 \mathrm{~h}$ with PBS alone or combined with the lipophilic antioxidant, butylated hydroxytoluene (BHT, $20 \mu \mathrm{M})$ and used as the source of native lipoprotein. An aliquot of the lipoprotein dialyzed with PBS alone was oxidized by exposure to $5 \mu \mathrm{M}$ $\mathrm{CuSO}_{4}$ for $8-20 \mathrm{~h}(32)$ in a shaking bath at $37^{\circ} \mathrm{C}$ followed by dialysis at $4^{\circ} \mathrm{C}$ for $18 \mathrm{~h}$ with PBS. As control experiments, buffer in the absence of lipoprotein was subjected to the copper oxidation procedure and subsequent dialysis. Protein concentration of lipoprotein was determined by the method of Peterson (33).

Lipid extraction of lipoproteins. Aliquots of native and copper-oxidized lipoprotein from a freshly isolated preparation of low density lipoprotein were first extracted with methanol-chloroform (2:1, vol/ vol) so that the proportion of methanol, chloroform, and water was maintained at $2: 1: 0.8$ by volume (34). After $1 \mathrm{~h}$ at room temperature, the mixture was centrifuged at $500 \mathrm{~g}$ for $10 \mathrm{~min}$ to precipitate the protein component which was assayed to determine recovery. To the supernatant, an additional 1 vol of chloroform and 1 vol of $0.15 \mathrm{M}$ $\mathrm{NaCl}$ was added and the solvent mixture was allowed to separate into two phases overnight at $4^{\circ} \mathrm{C}$. After centrifugation at $500 \mathrm{~g}$ for $10 \mathrm{~min}$, the lower organic phase containing total lipid was removed and saved. The upper aqueous phase was washed with 4 vol of chloroform, vortexed, and the separated lower phase was combined with the initial lipid extract. The amount of lipoprotein used was based on protein content. We measured the amount of protein after extraction and assumed that the total lipid in the extract was proportional to the total protein measured. An aliquot of lipid extract corresponding to $1 \mathrm{mg}$ of protein was evaporated under nitrogen and the lipid was spread as a thin film on silanized glass tubes. PBS $(1 \mathrm{ml})$ was added, the lipid was vigorously mixed for $5 \mathrm{~min}$ and the suspension was then further dispersed in a bath sonicator for $30 \mathrm{~min}$.

To remove lipid contaminants in the initial protein component, the protein fraction was extracted three additional times with methanolchloroform as described above. The protein pellet was dissolved in $1 \mathrm{~N}$ $\mathrm{NaOH}$, neutralized with $\mathrm{HCl}$, and then dialyzed for $48 \mathrm{~h}$ with two changes of PBS. Protein content of the dialyzed material was determined.

Lipid suspensions. L- $\alpha$-Lysophosphatidylcholine from egg yolk, L$\alpha$-phosphatidylcholine from egg yolk, L- $\alpha$-phosphatidylcholine, diarachidoyl, and l- $\alpha$-phosphatidylcholine, dilinoleoyl dissolved in chloroform or chloroform-ethanol were coated on the walls of silanized glass tubes during evaporation of the solvents under a stream of nitrogen gas. The lipids were hydrated with PBS, vortexed vigorously, and then sonicated in a bath sonicator for $30 \mathrm{~min}$ before use.

Assay of EDRF/NO in RFL-6 detector cells. RFL-6 cells contain abundant amounts of soluble guanylate cyclase (35) and EDRF or NO has been shown to directly activate this enzyme (36). Thus an increase in cyclic GMP in the RFL-6 cells can be used as a measure of EDRF/ NO activity (9). On experimental days 35-mm dishes of BAEC and/or RFL- 6 cells were washed twice with $2 \mathrm{ml}$ of Locke's solution ( $154 \mathrm{mM}$ $\mathrm{NaCl}, 5.6 \mathrm{mM} \mathrm{KCl}, 2 \mathrm{mM} \mathrm{CaCl}_{2}, 1 \mathrm{mM} \mathrm{MgCl}_{2}, 3.6 \mathrm{mM} \mathrm{NaHCO}_{3}, 5.6$ $\mathrm{mM}$ glucose and $10 \mathrm{mM}$ Hepes, $\mathrm{pH}$ 7.4). To prevent the formation of prostaglandins, endothelial cells were routinely pretreated with indomethacin $\left(10^{-5} \mathrm{M}\right)$ in Locke's buffer (final volume of $1 \mathrm{ml}$ ) at $37^{\circ} \mathrm{C}$ during a 30-min equilibration period. In the initial lipoprotein experiments using BAEC, the lipoprotein was usually added to BAEC during the equilibration time. In later experiments the lipoprotein or lipid suspensions were added to RFL- 6 cells just before the addition of NO. To prolong the short half-life of EDRF/NO which is rapidly destroyed by superoxide anions, superoxide dismutase $(100 \mathrm{U} / \mathrm{ml})$, an enzyme involved in the catalytic transformation of superoxide, was routinely added to BAEC before the addition of agents used to release EDRF. BAEC were stimulated with bradykinin $(1 \mu \mathrm{M})$ containing BSA $(0.01 \%)$ in Locke's buffer or the calcium ionophore A23187 $(1 \mu \mathrm{M})$. After a 2-3-min incubation period at $37^{\circ} \mathrm{C}$, the conditioned medium containing EDRF from BAEC was immediately transferred $(0.7 \mathrm{ml}$ of 
the total $1 \mathrm{ml}$ ) to RFL- 6 cells that had been preequilibrated for $30 \mathrm{~min}$ in $0.7 \mathrm{ml}$ of Locke's buffer containing $0.3 \mathrm{mM}$ of the phosphodiesterase inhibitor, 1-methyl-3-isobutyl xanthine (IBMX). At the end of another 2-min incubation period, the medium was aspirated from the RFL-6 cells, and the reaction was stopped by the addition of $1 \mathrm{ml}$ of ice-cold $\mathrm{HCl}(0.1 \mathrm{~N})$ to extract cGMP from the RFL-6 cells. In the experiments testing authentic NO or sodium nitroprusside, only RFL-6 cells were used. After a 30-min equilibration period, superoxide dismutase was first added to RFL-6 cells (as indicated), then buffer, lipoprotein, lipid, or other agent, and finally NO or nitroprusside. Preliminary experiments showed that NO, due to its high lability in the presence of oxygen, must be added directly to the cells from the gas-tight syringe and not be mixed with buffer or lipoprotein before its use. The percent of cGMP detected in RFL-6 cells upon prior mixing of NO and buffer in the presence or absence of superoxide dismutase was only $19 \pm 12 \%$ ( $n$ $=6$ ) of that when NO was added directly to the cells. In contrast, the nitroprusside-stimulated cGMP response was not altered by the prior mixing procedure. After incubation for $2 \mathrm{~min}$ with NO or 5-min with sodium nitroprusside, the medium from RFL-6 cells was aspirated, and $1 \mathrm{ml}$ of cold $0.1 \mathrm{~N} \mathrm{HCl}$ was added to terminate the stimulation. The 35-mm dishes of RFL-6 cells were placed on ice and agitated on a rotator to facilitate extraction of cGMP into the acid and cGMP was determined by radioimmunoassay (RPA 525, Amersham Corp., Arlington Heights, IL, or BT-340, Biomedical Technologies, Stoughton, MA). The $\mathrm{HCl}$ extract was adjusted to $\mathrm{pH} 5.8$ with $\mathrm{NaOH}, 50 \mu \mathrm{l}$ of $1 \mathrm{M}$ sodium acetate $\mathrm{pH} 5.8$ was added, and samples were diluted with 50 $\mathrm{mM}$ sodium acetate, $\mathrm{pH}$ 5.8. The remaining radioimmunoassay procedures of acetylation, addition of antiserum, ${ }^{125} \mathrm{I}-\mathrm{cGMP}$, and secondary antibody were done as described for the kit.

Determination of lipid peroxidation. The lipid peroxide content of native lipoprotein, copper-oxidized lipoprotein, lipids extracted from lipoproteins, or natural or synthetic lipids purchased commercially was measured fluorometrically as thiobarbituric acid-reactive substances (TBARS, 37). Lipoprotein or lipid in water was mixed with SDS, acetic acid, and thiobarbituric acid and heated for $60 \mathrm{~min}$ at $95^{\circ} \mathrm{C}$. After extraction with a mixture of $n$-butanol/pyridine $(15: 1, \mathrm{vol} / \mathrm{vol})$, the fluorescent reaction products in the upper organic layer were assayed on a spectrofluorometer with an excitation wavelength of $515 \mathrm{~nm}$ and an emission wavelength of $553 \mathrm{~nm}$. Freshly diluted tetraethoxypropane which yields malondialdehyde (MDA) was used as an external standard and the level of lipid peroxides is expressed as nanomole of MDA equivalents.

Data analysis. Two-way analyses of variance with replications were used to calculate differences for multiple treatments. One-way analysis of variance was used for single concentration curves. The probability $P$ is shown in the text for statistical significance of critical values of the variance ratio, $F$. Concentration response curves from individual experiments were fit by nonlinear regression analysis using a four-parameter logistic equation (38) to derive $\mathrm{EC}_{50}$ values for oxidized lipoprotein. The data are expressed as means \pm SEM or means \pm range when the number of experiments or determinations was 2 . Differences of means were determined by Student's unpaired $t$ test.

\section{Results}

$E D R F$ activity released from $B A E C$. Bradykinin, an endothelium-dependent vasodilator or the calcium ionophore A23187 stimulated the release of EDRF from the cultured bovine aortic endothelial cells. The transfer of the conditioned medium from stimulated BAEC to rat lung fibroblasts (RFL-6 cells) led to an increase in cGMP in these detector cells which serve as a sensitive bioassay for EDRF/NO activity (Fig. 1). This response by bradykinin or A23187 was blocked by preincubating BAEC in the presence of $N^{\mathrm{G}}$-monomethyl-L-arginine (L-NMMA), an inhibitor of the formation of EDRF/NO from L-arginine (data not shown). In addition, bradykinin or A23187 added directly

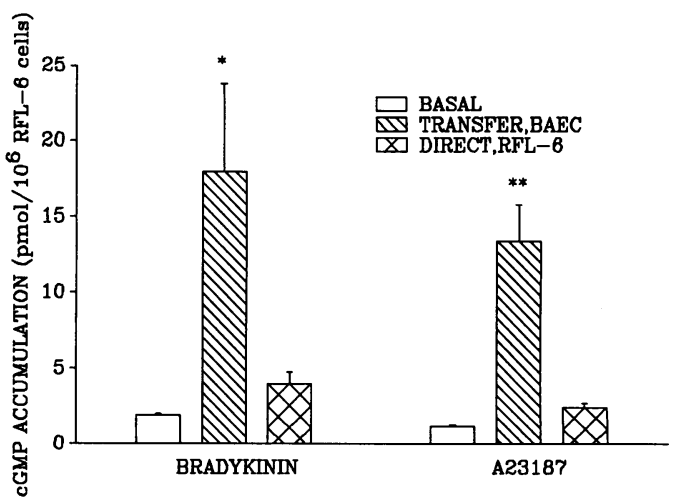

Figure 1. Stimulation of EDRF activity from BAEC by bradykinin and A23187. Confluent monolayers of BAEC were stimulated with bradykinin $\left(10^{-6} \mathrm{M}, 2 \mathrm{~min}\right)$ or A23187 $\left(10^{-6} \mathrm{M}, 3 \mathrm{~min}\right)$ in the presence of indomethacin $\left(10^{-5} \mathrm{M}\right)$ and superoxide dismutase $(100 \mathrm{U} / \mathrm{ml})$ to activate release of EDRF. The conditioned medium from BAEC (TRANSFER, BAEC) was quickly transferred to rat lung fibroblasts (RFL-6 cells) and the subsequent production of cGMP for a 2-min incubation was used as a measure of EDRF activity as previously described (9). Conditioned medium from nonstimulated BAEC was also added to RFL-6 detector cells $(B A S A L)$ and in some experiments bradykinin and A23187 were added directly to RFL-6 cells (DIRECT, $R F L-6)$. The data are the mean \pm SEM of 3-6 experiments. ${ }^{*} P<0.05$ vs. basal; ${ }^{* *} P<0.001$ vs. basal.

to RFL- 6 cells stimulated cGMP accumulation only $\sim 20 \%$ of that evoked by conditioned medium from BAEC stimulated by bradykinin or A23187 (Fig. 1). These results show that the transfer of stimulated EDRF from BAEC rather than a direct action of the bradykinin or A23187 on RFL-6 cells accounts for most of the activation of guanylate cyclase in RFL-6 detector cells.

Inhibition of EDRF activity released from $B A E C$ by $L D L$. Previous studies in blood vessels have shown that LDL modified by oxidation (ox-LDL) produces a marked loss in endothelium-dependent relaxation while native LDL ( $n-L D L)$ that is stringently protected from oxidation has very little effect on vascular relaxation (13). A 30-min exposure of BAEC to oxLDL produced a significantly greater inhibition of bradykininstimulated EDRF activity than did n-LDL protected by the antioxidant butylated hydroxytoluene $(20 \mu \mathrm{M})$ as shown in Fig. $2(P<0.005, n=2)$.

To test whether the actual release of EDRF from endothelial cells was blocked by lipoprotein, LDL was added to the detector cells (RFL-6) rather than to the BAEC. The degree of inhibition of EDRF action by lipoprotein added to RFL-6 cells was similar to that observed when LDL was added to BAEC (Fig. 3). These results suggest that the inhibitory effect of lipoprotein is due to an interaction between EDRF and LDL rather than having to postulate that LDL inhibits release of EDRF from BAEC. The inhibition was completely prevented when RFL- 6 cells, pretreated with LDL, were washed to remove the LDL before addition of the conditioned medium from stimulated BAEC (data not shown). Furthermore, prolonged incubation of the BAEC with LDL was not necessary because the extent of inhibition after 1 or 30 min incubation with LDL was similar (data not shown). However, LDL added to RFL-6 cells did not inhibit the accumulation of cGMP stimulated by sodium nitroprusside, a drug that directly activates guanylate cyclase via intracellular release of NO (Fig. 3). This result demon- 


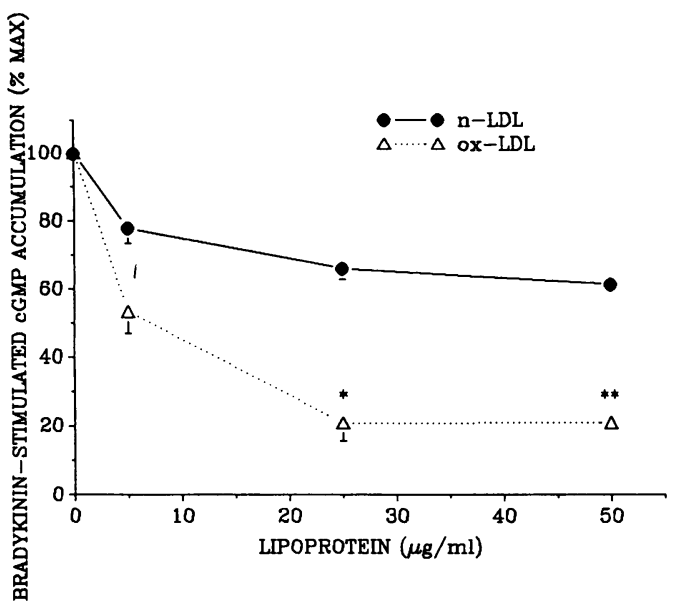

Figure 2. Effect of increasing concentrations of $\mathrm{n}-\mathrm{LDL}$ and copperoxidized LDL (ox-LDL) on bradykinin-stimulated EDRF activity released from BAEC. Confluent monolayers of BAEC were incubated with or without $n-L D L$ (protected by antioxidant butylated hydroxytoluene [BHT $20 \mu \mathrm{M}$ ]) or ox-LDL for $30 \mathrm{~min}$ and were then stimulated with bradykinin $\left(10^{-6} \mathrm{M}\right)$ in the presence of indomethacin $\left(10^{-5}\right.$ $\mathrm{M})$ and superoxide dismutase $(100 \mathrm{U} / \mathrm{ml})$ for $2 \mathrm{~min}$. The conditioned medium from BAEC was immediately transferred to RFL-6 cells and the subsequent stimulation of cGMP accumulation was used as a measure of EDRF activity as described in Methods. cGMP accumulation is expressed as the percent of the control response by bradykinin in the absence of lipoprotein. The mean value of bradykinin-stimulated cGMP in the absence of lipoprotein was $8.9 \pm 0.1 \mathrm{pmol}$ cGMP $/ 10^{6}$ RFL- 6 cells in this representative experiment. Each point represents the mean \pm range of duplicate incubations. Two-way analysis of variance with replicates showed that the inhibition by ox-LDL was more marked than that by $\mathrm{n}-\mathrm{LDL}(P$ $<0.005$ ) and that there was a concentration effect by the lipoproteins $(P<0.005) .{ }^{*} P<0.05$ vs. $\mathrm{n}-\mathrm{LDL} ;{ }^{* *} P<0.01$ vs. $\mathrm{n}-\mathrm{LDL}$. The experiment was repeated once with similar results.

strates that LDL did not directly inhibit guanylate cyclase in the detector cells.

Effect of native and oxidized LDL on nitric oxide activation of cGMP. Because LDL inactivated EDRF after it was released from BAEC, we wondered if LDL would inactivate authentic NO because there is substantial evidence suggesting that EDRF is NO or a related compound (3). Authentic NO, when added directly to RFL-6 cells, stimulated cGMP accumulation in the detector system in a concentration-dependent manner (Fig. 4). The NO-stimulated cGMP accumulation was attenuated by the addition of $\mathrm{n}-\mathrm{LDL}$ or ox-LDL $(50 \mu \mathrm{g} / \mathrm{ml})$ just before stimulation by different concentrations of NO (Fig. $4, P<0.005$ ). Dose-response curves for $\mathrm{n}-\mathrm{LDL}$ and ox-LDL demonstrated that ox-LDL was more potent and efficacious in inhibiting the cGMP accumulation induced by NO in RFL- 6 cells compared to $\mathrm{n}$-LDL (Fig. $5, P<0.005$ ). The $\mathrm{EC}_{50}$ for ox-LDL was $1.2 \pm 0.2 \mu \mathrm{g}(n=2)$.

Effect of native and oxidized HDL on NO activation of $c G M P$. The inhibition of NO activity in lipoproteins was not limited to LDL but also occurred with human high density lipoprotein $\left(\mathrm{HDL}_{3}\right.$ ) (Fig. 6). The oxidized form of $\mathrm{HDL}_{3}$ (ox$\left.\mathrm{HDL}_{3}\right)(150 \mu \mathrm{g})$ almost completely blocked the NO stimulation of cGMP $(P<0.005)$ and the inhibition was significantly greater than that seen with $\mathrm{n}-\mathrm{HDL}_{3}(150 \mu \mathrm{g})(P<0.05)$. Additional experiments at a single concentration of $\mathrm{NO}$ and two concentrations of $\mathrm{HDL}_{3}$ confirmed that the inhibition of ox-

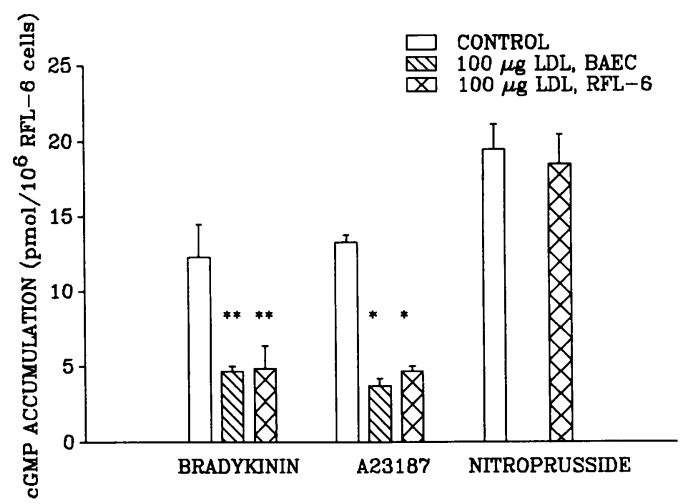

Figure 3. Effect of LDL on cGMP responses activated by bradykinin, calcium ionophore A23187, or sodium nitroprusside. BAEC were stimulated by bradykinin $\left(10^{-6} \mathrm{M}\right)$ for $2 \mathrm{~min}$ or $\mathrm{A} 23187\left(10^{-6} \mathrm{M}\right)$ for $3 \mathrm{~min}$ in the presence (diagonal bars) or absence (control, open bars) of LDL $(100 \mu \mathrm{g})$ during a 30 -min preincubation period. The conditioned medium containing EDRF was then immediately transferred from BAEC to RFL- 6 cells. In some cases, the conditioned medium from BAEC stimulated in the absence of LDL was transferred to detector RFL- 6 cells that had been preincubated with LDL $(100 \mu \mathrm{g})$ for 30 min (cross-hatched bars). Sodium nitroprusside $\left(10^{-5} \mathrm{M}\right)$ was added directly to RFL- 6 cells for $5 \mathrm{~min}$ in the absence (control, open bars) or in the presence of $100 \mu \mathrm{g} \mathrm{LDL} \mathrm{(30-min} \mathrm{preincubation,} \mathrm{cross-}$ hatched bar). LDL inhibited the activation of CGMP accumulation by EDRF whether the LDL was added to the BAEC or RFL- 6 cells. LDL did not inhibit the action of sodium nitroprusside. The data are the mean \pm SEM of $2-4$ determinations. ${ }^{*} P<0.01$ vs. control; ${ }^{* *} P$ $<0.001$ vs. control.

$\mathrm{HDL}_{3}$ was more robust than that of $\mathrm{n}-\mathrm{HDL}_{3}$. In a single experiment the concentration of ox- $\mathrm{HDL}_{3}$ needed to reduce the NOstimulated cGMP accumulation by $50 \%\left(\mathrm{EC}_{50}\right)$ was $\sim 1 \mu \mathrm{g} / \mathrm{ml}$. Exposure of cells to buffer (PBS with no added lipoproteins)

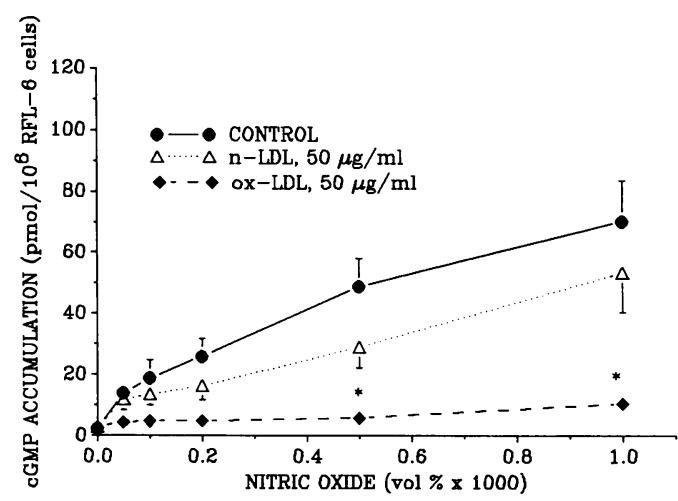

Figure 4. Effect of n-LDL and ox-LDL on NO-stimulated cGMP accumulation in RFL- 6 cells. SOD $(100 \mathrm{U} / \mathrm{ml})$ and buffer in the presence or absence (control) of $50 \mu \mathrm{g}$ of $\mathrm{n}-\mathrm{LDL}$ or ox-LDL were added to RFL- 6 cells just before the addition of varying amounts of NO dissolved in deoxygenated water $(5,10,20,50$, or $100 \mu \mathrm{l}$ of $0.01 \% \mathrm{NO}$ $\mathrm{vol} / \mathrm{vol}$ to a final volume of $1 \mathrm{ml}$ ). After $2 \mathrm{~min}$ incubation with $\mathrm{NO}$, the reaction was stopped by aspiration of the supernatant and the addition of $1 \mathrm{ml}$ of cold $0.1 \mathrm{~N} \mathrm{HCl}$ and CGMP assayed. Each point shows the mean \pm SEM of three different experiments; for some points, the error bars are smaller than the symbols. Two-way analysis of variance with replicates showed inhibition by $\mathrm{n}-\mathrm{LDL}(P<0.05)$ and by ox-LDL $(P<0.005)$ was greater than control but inhibition by ox-LDL was more marked than that by $\mathrm{n}-\mathrm{LDL}(P<0.005) .{ }^{*} P$ $<0.05$ vs. $n-L D L$. 


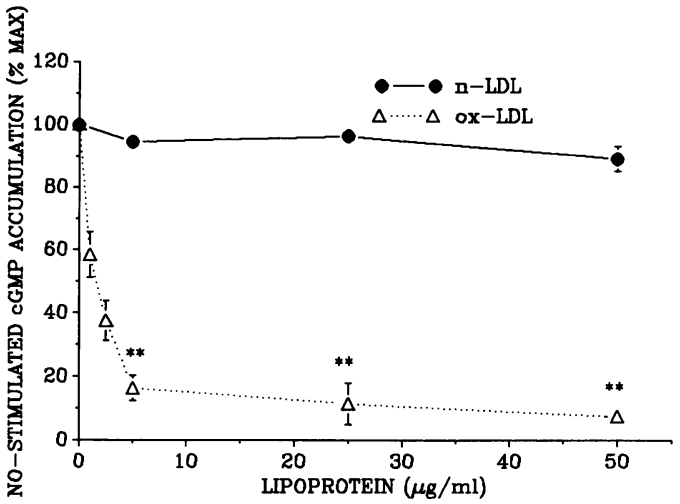

Figure 5. Effect of increasing concentrations of $\mathrm{n}-\mathrm{LDL}$ and ox-LDL on NO stimulated cGMP accumulation in RFL-6 cells. SOD (100 $\mathrm{U} / \mathrm{ml}$ ) and varying amounts of $\mathrm{n}-\mathrm{LDL}$ or ox-LDL were added to the RFL- 6 cells just before the addition of NO dissolved in deoxygenated water $(50 \mu \mathrm{l}$ of $0.01 \% \mathrm{NO}$ vol/vol). After $2 \mathrm{~min}$ incubation with NO, the reaction was stopped by aspiration of the supernatant and the addition of $1 \mathrm{ml}$ of cold $0.1 \mathrm{~N} \mathrm{HCl}$ and cGMP assayed. Each point shows the mean \pm range of two different experiments; for some points, the error bars are smaller than the symbols. Inhibition was greater by ox-LDL than by $\mathrm{n}-\mathrm{LDL}(P<0.005$, two-way analysis of variance). ${ }^{* *}$ cGMP response was less with ox-LDL than with $\mathrm{n}-\mathrm{LDL}(P<0.001)$.

that had been subjected to the same oxidation and dialysis procedures used to oxidize lipoprotein did not decrease the cGMP response to NO; also, neither n-LDL nor ox-LDL inhibited nitroprusside-stimulated cGMP accumulation in RFL-6 cells (data not shown).

Reversal of inhibitory effect of $L D L$ on NO. Experiments were undertaken to find agents that might reverse the inhibitory effect of LDL on NO. Superoxide anions are ubiquitously produced by oxidation within cells and have been shown to destroy labile EDRF/NO (3). We used various concentrations of SOD to determine whether superoxide anion was involved

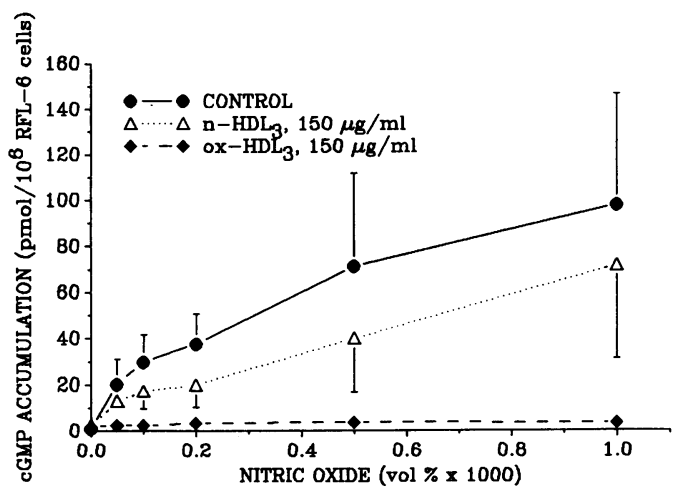

Figure 6. Effect of $\mathrm{n}-\mathrm{HDL}_{3}$ and $\mathrm{ox}-\mathrm{HDL}_{3}$ on NO-stimulated cGMP accumulation in RFL-6 cells. SOD $(100 \mathrm{U} / \mathrm{ml})$ and buffer in the presence or absence (control) of $150 \mu \mathrm{g}$ of $\mathrm{n}-\mathrm{HDL}_{3}$ or $\mathrm{ox}-\mathrm{HDL}_{3}$ were added to RFL-6 cells just before the addition of varying amounts of NO dissolved in deoxygenated water $(5,10,20,50$, or $100 \mu$ lof $0.01 \%$ $\mathrm{NO} \mathrm{vol} / \mathrm{vol}$ to a final volume of $1 \mathrm{ml}$ ). After $2 \mathrm{~min}$ incubation with $\mathrm{NO}$, the reaction was stopped by aspiration of the supernatant and the addition of $1 \mathrm{ml}$ of cold $0.1 \mathrm{~N} \mathrm{HCl}$ and cGMP assayed. Each point is the mean \pm range of two different experiments; for some experiments the error bars are smaller than the symbols. Two-way analysis of variance showed that the inhibition was greater by ox$\mathrm{HDL}_{3}$ than that by $\mathrm{n}-\mathrm{HDL}_{3}(P<0.05)$ or NO alone $(P<0.005)$. in the inhibition of NO-stimulated cGMP accumulation by ox-LDL. As expected, in the absence of lipoproteins, SOD, which delays the destruction of NO, enhanced the effectiveness of NO to activate CGMP production in a concentration-related manner (Fig. 7, $P<0.05$ ). The maximal cGMP response was seen in the presence of 20-100 U of SOD, about a threefold increase above the value found in the absence of SOD (Fig. 7). These results were confirmed in a larger series of experiments $(P<0.001)$. The presence of ox-LDL $(2.5$ and $25 \mu \mathrm{g} / \mathrm{ml})$ markedly attenuated the cGMP response at each concentration of SOD when compared to controls in the absence of lipoprotein (Fig. $7, P<0.005$ ) indicating that SOD did not antagonize the inhibitory effect of ox-LDL.

The addition of the antioxidant butylated hydroxytoluene to copper-oxidized LDL during dialysis subsequent to the oxidation procedure and during incubation with RFL-6 cells partially reversed the inhibition by ox-LDL on NO activation of cGMP (Fig. 8, $P<0.01$, when ox-LDL without BHT was compared to ox-LDL with BHT). However, the addition of $\alpha$-tocopherol ( $50 \mu \mathrm{M}$, an endogenous chain-breaking antioxidant), catalase (1,600 U, an enzyme that destroys hydrogen peroxide), or glutathione peroxidase $(1 \mathrm{U} / \mathrm{ml}$, an enzyme that catalyzes destruction of hydrogen peroxide and lipid hydroperoxides) plus reduced glutathione $(0.25 \mathrm{mM})$, when added to RFL-6 cells during the incubation period, did not alter the inhibitory effect of ox-LDL.

Effect of lipid and protein components of native and oxidized LDL on NO-stimulated cGMP accumulation. To determine which component of ox-LDL inhibited the action of NO, we extracted lipids and proteins from ox-LDL and n-LDL. Neither intact $n-L D L$ nor extracted lipid or protein from $n-$ LDL inhibited NO-stimulated cGMP accumulation in RFL-6 cells (Fig. $9 \mathrm{~A}$ ). However, lipid extracted from ox-LDL inhibited the cGMP response to a similar extent as the intact oxLDL while the proteins extracted from the ox-LDL did not inhibit the cGMP response (Fig. $9 B$ ).

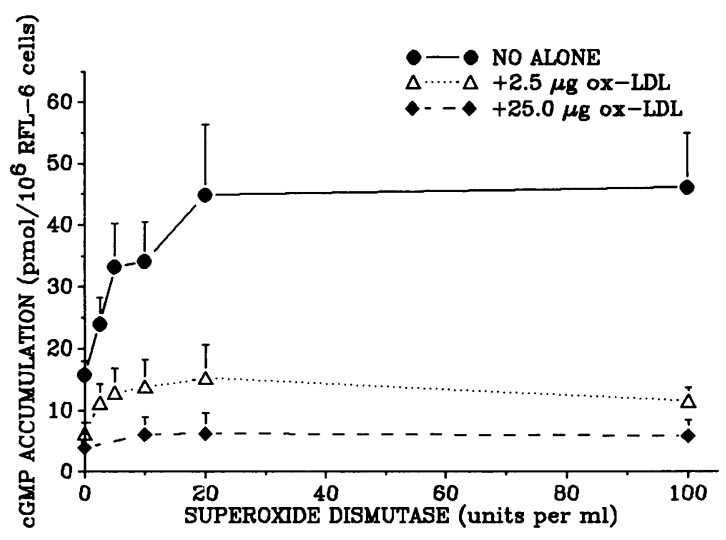

Figure 7. Effect of superoxide dismutase (SOD) on NO-stimulated cGMP accumulation in RFL-6 cells in the presence or absence of ox-LDL. Varying amounts of SOD and ox-LDL ( 2.5 or $25 \mu \mathrm{g} / \mathrm{ml})$ were added to RFL-6 cells just before the addition of NO ( $50 \mu \mathrm{l}$ of $0.01 \% \mathrm{NO} \mathrm{vol} / \mathrm{vol}$ ). After $2 \mathrm{~min}$ incubation, the reaction was stopped and cGMP assayed. SOD increased the NO response. Both concentrations of ox-LDL decreased the response to NO $(P<0.005$, two-way analysis of variance) and the decrement was not overcome by increasing concentrations of SOD. Each point is the mean \pm SEM for three different experiments except for the $25 \mu \mathrm{g}$ ox-LDL points which are the mean \pm range for two experiments. 


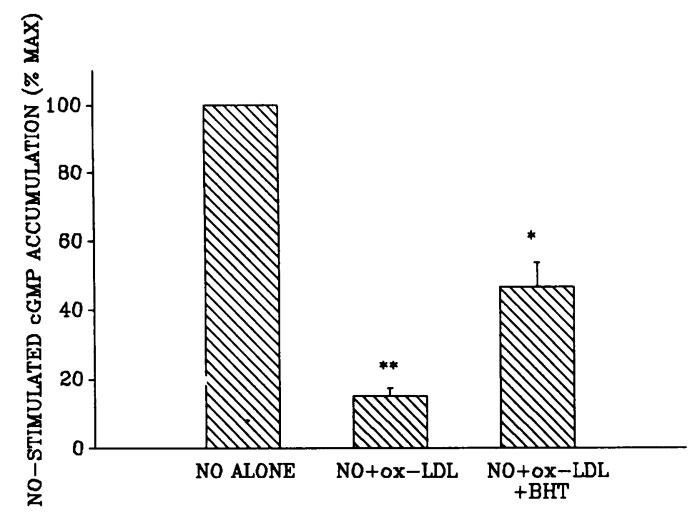

Figure 8. Partial reversal of ox-LDL inhibition of NO-stimulated cGMP by the antioxidant butylated hydroxytoluene (BHT). RFL-6 cells were stimulated by $\mathrm{NO}(50 \mu \mathrm{l}$ of $0.01 \%(\mathrm{vol} / \mathrm{vol}) \mathrm{NO})$ for $2 \mathrm{~min}$ in the absence of lipoprotein (NO ALONE), in the presence of $25 \mu \mathrm{g} /$ $\mathrm{ml}$ of ox-LDL, or in presence of $25 \mu \mathrm{g} / \mathrm{ml}$ of ox-LDL that had been previously dialyzed with the antioxidant BHT $(20 \mu \mathrm{M})$ and added to cells that had been preincubated with BHT for $30 \mathrm{~min}$. The bars represent the mean \pm SEM of four experiments. ${ }^{* *} \mathrm{NO}+$ ox-LDL was significantly less than NO ALONE, $P<0.001 ;{ }^{*} \mathrm{NO}+$ ox-LDL + BHT was significantly greater than NO + ox-LDL, $P<0.01$.

Consequently, the lipid component of ox-LDL accounts for the inhibition observed with the intact lipoprotein with a negligible contribution of the protein component. To determine whether the degree of inhibition of the cGMP response was related to the lipid peroxidation of the lipoprotein, the formation of TBARS, an index of lipid peroxidation, was measured. The formation of TBARS was higher in intact ox-LDL and its extracted lipid than in n-LDL or its extracted lipid $(91 \pm 6 \mathrm{nmol}$ malondialdehyde/mg protein for intact ox-LDL vs. $10 \pm 5$ for intact n-LDL, $P<0.001, n=4 ; 24 \pm 0.3$ for ox-LDL lipid vs. $8 \pm 6$ for $\mathrm{n}$-LDL lipid, $P<0.05, n=4$ ).

Effect of other lipids and protein on NO-stimulated cGMP accumulation. To test further the hypothesis that oxidized lipids were responsible for the inhibition of NO-stimulated cGMP accumulation, we compared two natural and two synthetic phosphatidylcholines with a fatty acid-free protein. BSA did not alter the NO-stimulated CGMP response (Fig. 10). In contrast, varying degrees of inhibition was observed with the phospholipids, with the largest effect with dilinoleoyl phosphatidylcholine, which also was the only one of these four lipids used in which any formation of TBARS could be detected.

Effect of oxygen free radicals on NO-stimulated cGMP accumulation. Ascorbate $(0.2 \mathrm{mM})$ and ferrous sulfate $(0.1 \mathrm{mM})$, which promote lipid peroxidation in the cell (39), inhibited NO-stimulated cGMP accumulation in RFL-6 cells (Fig. 10). We also tested two sources of oxygen free radicals, often proposed as the causative factor in lipid peroxidation. Superoxide anion, enzymatically generated by reacting hypoxanthine (100 $\mu \mathrm{M})$ with xanthine oxidase $(0.02-1 \mathrm{U} / \mathrm{ml})$ markedly reduced the NO-stimulated cGMP response to $\sim 5 \%$ of values in controls. Reagent hydrogen peroxide $(1 \mathrm{mM})$ was also effective in attenuating the cGMP response.

\section{Discussion}

The present experiments show that lipoproteins impair EDRF and NO activity as measured by cGMP accumulation in cultured RFL-6 cells, analogous to the inhibitory effect of lipopro- teins on endothelium-dependent vascular relaxation previously reported. LDL modified by oxidation markedly impaired EDRF activity from bovine aortic endothelial cells (BAEC) in response to both bradykinin and the calcium ionophore A23187. In addition, ox-LDL inhibited stimulation of cGMP accumulation by authentic NO. However, ox-LDL did not inhibit activation of guanylate cyclase by sodium nitroprusside which releases NO intracellularly. Together, these results suggest that the attenuation of EDRF-stimulated cGMP accumulation by oxidized lipoproteins involves inactivation of EDRF/ NO. The oxidized forms of both LDL and $\mathrm{HDL}_{3}$ are highly potent with $\mathrm{EC}_{50} \mathrm{~s}$ of $\sim 1 \mu \mathrm{g} / \mathrm{ml}$. Lipid extracted from ox-LDL was as effective as the intact molecule of ox-LDL in attenuating NO-stimulated cGMP response. In contrast, the extracted protein component of ox-LDL did not inhibit NO-activated cGMP accumulation. Other lipids such as natural and synthetic phosphatidylcholines and lysophosphatidylcholine, did induce varying degrees of inhibition of the cGMP response.
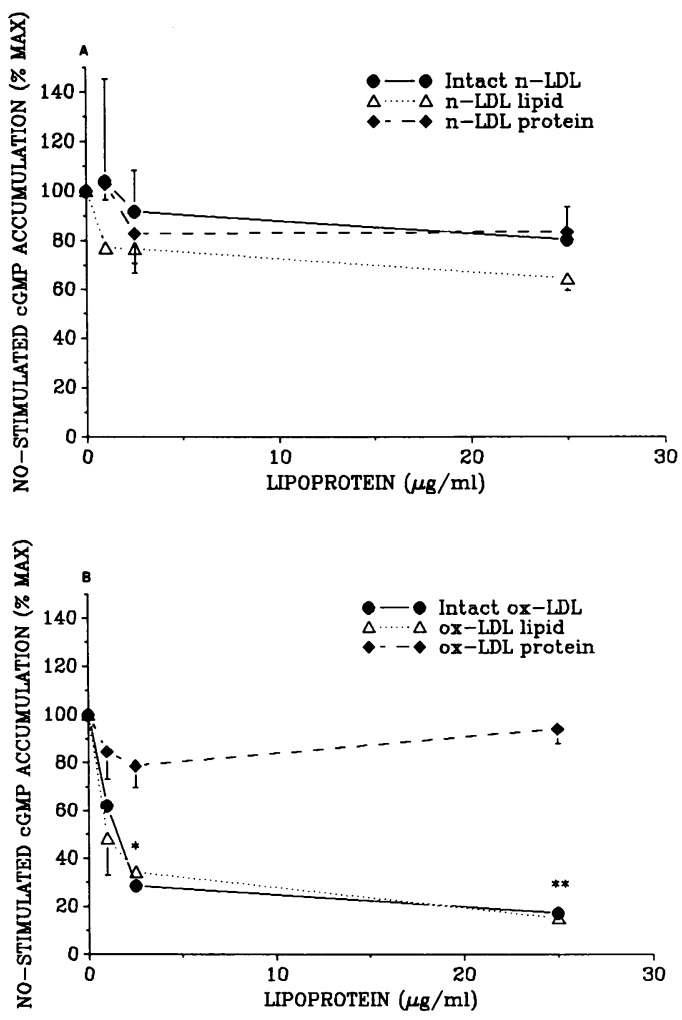

Figure 9. Comparison of the effects of the lipid and protein components of $\mathrm{n}-\mathrm{LDL}$ and ox-LDL on NO-stimulated cGMP accumulation in RFL-6 cells. Lipids and proteins were extracted from intact $n-L D L$ or intact ox-LDL by methanol-chloroform as described in Methods. Protein and lipid content were estimated as described in Methods. SOD $(100 \mathrm{U} / \mathrm{ml})$ and buffer in the presence or absence of varying amounts of intact n-LDL, n-LDL extracted lipid, or n-LDL extracted protein $(A)$ or intact ox-LDL, ox-LDL extracted lipid, or ox-LDL extracted protein $(B)$ were added to RFL-6 cells just before the addition of NO dissolved in deoxygenated water $(50 \mu \mathrm{l}$ of $0.01 \% \mathrm{NO}$ vol/ vol). After incubation for $2 \mathrm{~min}$, cGMP was assayed as described in Methods. Each point is the mean \pm SEM for three different experiments except for those involving protein which are the mean \pm range for two experiments. Both intact ox-LDL and its extracted lipid inhibited cGMP to about the same extent with negligible effect by protein extracted from ox-LDL $(P<0.05$ by two-way analysis of variance). ${ }^{*} P<0.05$ vs. ox-LDL protein; ${ }^{* *} P<0.001$ vs. ox-LDL protein. 


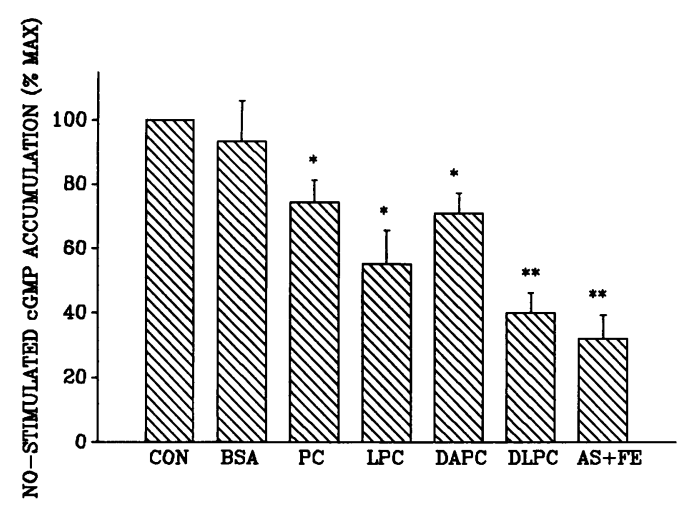

Figure 10. Comparison of the effects of natural and synthetic lipids and BSA on NO-stimulated cGMP accumulation in RFL-6 cells. RFL-6 cells, in the presence of SOD $(100 \mathrm{U} / \mathrm{ml})$, were treated with either no addition (CON) or by the addition of BSA (BSA fatty acid free, $50 \mu \mathrm{g} / \mathrm{ml}$ ), phosphatidylcholine from egg yolk (PC, $40 \mu \mathrm{g} / \mathrm{ml}$ ), lysophosphatidylcholine from egg yolk (LPC, $50 \mu \mathrm{g} / \mathrm{ml}$ ), diarachidoyl phosphatidylcholine (DAPC, $40 \mu \mathrm{g} / \mathrm{ml})$, dilinoleoyl phosphatidylcholine $(D L P C, 40 \mu \mathrm{g} / \mathrm{ml})$, or ascorbate $(0.2 \mathrm{mM})+$ ferrous sulfate $(0.1$ $\mathrm{mM})(A S+F E)$. NO dissolved in deoxygenated water $(50 \mu \mathrm{l}$ of $0.01 \%$ $\mathrm{NO} \mathrm{vol} / \mathrm{vol}$ ) was then immediately added; after a 2-min incubation the reaction was stopped and CGMP assayed. cGMP responses were compared to controls (CON). In additional experiments, 25 and 100 $\mu \mathrm{g} / \mathrm{ml}$ of BSA ( $n=3$ at each concentration) were also ineffective in attenuating NO stimulated cGMP accumulation in RFL-6 cells (data not shown). Each bar shows the mean \pm SEM for three different experiments except for PC when $n=5$ experiments. *Significantly different from CON, $P<0.01$; ${ }^{* *}$ significantly different from CON, $P$ $<0.001$.

We have used the sensitive method of Ishii et al. (9) to measure EDRF activity as an increase in cGMP accumulation in fetal rat lung fibroblasts (RFL-6) because this detector cell contains abundant soluble guanylate cyclase activity. The fibroblast detector cell is analogous to vascular smooth muscle because relaxation induced by EDRF is thought to be due to activation of soluble guanylate cyclase and subsequent accumulation of cGMP within vascular smooth muscle to result in relaxation (7). We have stimulated the release of EDRF from cultures of endothelial cells isolated from bovine aorta (BAEC) because the use of cell cultures eliminates extraneous effects on other components of the blood vessel wall which often complicates interpretation of studies done on intact blood vessels either in vitro or in vivo. The addition of bradykinin or the calcium ionophore A23187 to BAEC stimulated the release of EDRF into the medium, which, when rapidly transferred to RFL-6 cells, activated an increase in cGMP accumulation $\sim$ 10-fold above the basal concentration of cGMP. In contrast, adding bradykinin and A23187 directly to RFL-6 cells elevated cGMP only about twofold above basal values. The factor released in the conditioned medium from BAEC and detected by RFL-6 cells was confirmed to be a nitric oxide-like EDRF because its synthesis was blocked by preincubation of BAEC with $N^{G}$-monomethyl-L-arginine (L-NMMA), a selective inhibitor of NO production. This cell culture system was used to localize the site of action of lipoproteins in acutely impairing the effects of EDRF.

Both native $(11,12,14,15)$ and ox-LDL $(12,13,23,24)$ have been reported to inhibit endothelium-dependent relaxation in isolated normal blood vessels. The inhibitory effects of
n-LDL on vascular relaxation apparently depends upon the agent used to contract blood vessels and the concentration of $\mathrm{n}$-LDL. $\mathrm{n}-\mathrm{LDL}$, at concentrations of $0.5-2 \mathrm{mg} / \mathrm{ml}$, comparable to that found in hypercholesterolemic plasma $(11,12)$, blocked endothelium-dependent relaxation in aorta precontracted by norepinephrine, epinephrine, or 5-hydroxytryptamine, but not by phenylephrine. No inhibition of n-LDL $(100 \mu \mathrm{g} / \mathrm{ml})$ on aortas precontracted with phenylephrine was observed when special precautions were taken to avoid oxidation (13). In our experiments, the effects of ox-LDL were found at concentrations in the micrograms-per-milliliter range. It has also been shown that minimally oxidized LDL obtained by storage or mild iron oxidation, although indistinguishable from native LDL by the LDL receptor, was capable at very low concentrations $(0.12 \mu \mathrm{g} / \mathrm{ml})$ to increase binding of monocytes and production of monocyte chemotactive factor in endothelial cells, one of the earliest events in formation of foam cells in atherogenesis (26). When we used native LDL protected by antioxidants, the inhibitory effect of n-LDL on cGMP accumulation was small compared to the marked attenuation induced by ox-LDL.

The major purpose of our experiments was to determine the locus of action of LDL on inhibiting the capacity of EDRF to activate cGMP accumulation. In isolated blood vessels, it has been found by several groups that LDL attenuates EDRFmediated relaxation of smooth muscle; however, the mechanism by which this occurs has been uncertain. Experiments on vascular relaxation of normal blood vessels suggest lipoproteins may block production of $\operatorname{EDRF}(14)$, affect $G$ proteins in signal transduction (13), or produce functional changes in the endothelium (15).

In our experiments, the inhibitory effect of ox-LDL on EDRF activity is best explained by a chemical interaction between LDL and EDRF rather than inhibition of release of EDRF from endothelial cells or inhibition of guanylate cyclase by lipoproteins. Because ox-LDL inhibited EDRF activity stimulated by A23187 as well as bradykinin, it is highly unlikely that the effects of LDL involve interactions with neurotransmitter or hormone receptors on the endothelial cells. When oxLDL was added to the detector RFL-6 cells rather than to the BAEC, we found that the degree of inhibition of EDRF activity was similar to that seen when LDL was added directly to the BAEC. In addition, ox-LDL inhibited the CGMP response to authentic NO. These data suggest that the inhibitory effect of ox-LDL is due to a direct interaction between ox-LDL and NO although we have not excluded the possibility that LDL could have an additional effect on BAEC leading to inhibition of release of EDRF from these cells. The hypothesis that the effect of LDL involved a direct interaction with $\mathrm{NO}$ is also supported by the experiments which showed that if the RFL-6 cells were incubated with LDL for $30 \mathrm{~min}$, the effect of LDL on NO did not occur if the extracellular LDL was washed out of the culture dish. This suggests that any LDL that may have been taken up by the detector RFL-6 cells was insufficient to modify responses to NO and that the effects of LDL were actually mediated by the extracellular LDL. LDL interacted rapidly with NO to attenuate its capacity to activate cGMP accumulation in the RFL- 6 cells because this effect could be detected when NO was added directly to the cells in the presence of LDL. Furthermore, LDL did not inhibit the capacity of sodium nitroprusside to activate cGMP accumulation in the RFL-6 cells indicating that LDL does not directly inhibit guanylate cyclase and 
that the guanylate cyclase enzyme in the RFL-6 cells was functional in the presence of LDL. The nature of the chemical interaction between NO and ox-LDL is uncertain. There are several major general possibilities. Higher redox state nitrogen oxides might be formed by interaction of NO with ox-LDL. Alternatively, NO might form an adduct with the lipid moeity of ox-LDL.

These results in our cell culture model system are in good agreement with a variety of studies conducted in isolated vascular smooth muscle and support the appropriateness of this model. For example, in rabbit aorta, LDL inhibits endothelium-dependent relaxation stimulated by both cell surface receptors and A23187 (11, 12, 15). In blood vessels, oxidized LDL has been found to inhibit relaxations evoked by exogenous NO (12) and it has been suggested that LDL may react with or sequester NO (12). However, VLDL, LDL, or HDL, which reversed endothelium-dependent relaxation induced by acetylcholine and A23187, did not inhibit relaxation induced by authentic NO (14). The inability of lipoproteins to inhibit relaxation elicited by nitroprusside has been found in vascular smooth muscle (11-15). Inhibition of relaxation by native LDL occurs when LDL is added to vessels immediately before addition of acetylcholine (12). The reversibility of inhibition of relaxation mediated by native LDL and HDL has also been demonstrated in aorta $(12,14,15)$.

Although bradykinin and the calcium ionophore A23187 stimulates the release of both EDRF and prostacyclin from endothelial cells, indomethacin was routinely used in our experiments with BAEC to inhibit cyclooxygenase and the subsequent synthesis of endogenous prostacyclin. Consequently, the inhibition by lipoproteins cannot be attributed to cyclooxygenase products. Although superoxide anions and/or hydrogen peroxide may be partially involved during the formation of oxidized lipoproteins by endothelial cells or copper sulfate (40), these oxygen free radicals do not appear to mediate the inhibitory effects of lipoproteins. We observed no reversal of the attenuated cGMP response induced by oxidized lipoproteins by superoxide dismutase, an enzyme that inactivates superoxide anion; catalase, an enzyme that inactivates hydrogen peroxide; or glutathione peroxidase, an enzyme that inactivates hydrogen peroxide and lipid hydroperoxides. However, we did find partial antagonism of the lipoprotein-induced decrease in cGMP accumulation by BHT which blocks all free radicals, but surprisingly, not by $\alpha$-tocopherol (vitamin E), the common endogenous antioxidant which also is a general free radical scavenger. Because lipid peroxidation can be initiated by the reaction of oxygen and polyunsaturated lipids, the presence of the lipid peroxides within ox-LDL may be the important inhibitory factor.

To determine whether the lipid or protein component of ox-LDL was responsible for the inhibitory effect on the cGMP response, we extracted lipid from both n-LDL and ox-LDL. Lipid extracted from ox-LDL inhibited NO-stimulated cGMP accumulation to about the same extent as intact ox-LDL; however, the protein component of ox-LDL did not inhibit the cGMP response. In contrast, neither lipid nor protein extracted from n-LDL inhibited NO-stimulated cGMP accumulation. In analogous experiments in rabbit aorta, lipid extracted from LDL oxidized by incubation with endothelial cells also impairs endothelium-dependent relaxation to about the same magnitude as the intact modified LDL (13). Delipidation of HDL prevents the reversal of endothelium-dependent relaxation
(14). The results from cell culture and from rabbit aorta suggest that the lipid in ox-LDL can account for the inhibitory effects in the two different systems.

A critical role of lipid in the inhibitory effect of NO-stimulated cGMP was confirmed with natural and synthetic phosphatidycholines. We tested lysophosphatidylcholine because its content is increased in oxidized LDL (28). We used a synthetic phosphatidylcholine containing linoleic acid which comprises $92 \%$ of the polyunsaturated fatty acids in human LDL (41). All lipids tested inhibited NO-stimulated cGMP accumulation. Others have found marked inhibitory effects of lysophosphatidylcholine (13), phosphatidylcholine, phosphatidylinositol, and sphingomyelin (14) on vascular relaxation induced by acetylcholine. BSA (fatty acid free) did not decrease NO-stimulated cGMP response nor did the extracted protein components of n-LDL or ox-LDL suggesting that these specific proteins do not contribute to this effect. However, these results do not exclude the possibility of interaction of other native proteins with NO.

In our experiments we found the inhibition of NO-stimulated CGMP was not specific for LDL but was also seen with HDL. VLDL, LDL, and HDL from rabbit plasma inhibited vascular relaxation in rabbit aorta induced by acetylcholine or A23187 (14), whereas HDL had no inhibitory effect on thrombin-induced relaxation in porcine coronary artery (15). Although LDL is converted to its oxidized form by endothelial cells, smooth muscle cells, and monocytes and macrophages, the major cell types in the arterial wall (16), it is not known whether HDL accumulates and is similarly converted to its oxidized form in the arterial wall.

There has been considerable interest in the relationship between hyperlipidemia and atherosclerosis on the one hand and impaired endothelial-dependent relaxation on the other. In various animal models of hypercholesterolemia, atherosclerotic changes in large vessels have been associated with impaired relaxation mediated by EDRF-dependent vasodilators (17-21, 42, 43). However, as discussed above, acutely elevated concentrations of lipoproteins can inhibit relaxation dependent on EDRF. The relationship between the changes seen with chronic elevations of cholesterol and the acute effects of lipoproteins is not clear. There is evidence that with chronic elevations in cholesterol, endothelial cell dysfunction can be reversed by infusions of arginine (22). This suggests the possibility that there may also be impaired release of EDRF in that setting.

The present results with cultured endothelial cells suggest that oxidized lipoproteins inhibit endothelium-dependent vascular relaxation by inactivation of EDRF after its release from endothelial cells and that the lipid component of the oxidized lipoprotein can account for the attenuated response. The chemical nature of this interaction remains to be determined. Also, in the setting of prolonged hypercholesterolemia, the relative contributions of inactivation of EDRF and the role of endothelial cell dysfunction requires further investigation. The results of such studies will have important implications for the therapy of functional disorders of vascular smooth muscle in patients with hypercholesterolemia.

\section{Acknowledgments}

We gratefully thank Dr. K. Ishii for his help in establishing the RFL-6 assay in our laboratory. 
This work was supported in part by the Research Service of the Department of Veterans Affairs and National Institutes of Health grant \#HL-41315. Dr. Hoffman is an Established Investigator of the American Heart Association.

\section{References}

1. Furchgott, R. F., and J. V. Zawadzki. 1980. The obligatory role of endothelial cells in the relaxation of arterial smooth muscle by acetylcholine. Nature (Lond.). 288:373-376.

2. Furchgott, R. F., and P. M. Vanhoutte. 1989. Endothelium-derived relaxing and contracting factors. FASEB (Fed. Am. Soc. Exp. Biol.) J. 3:2007-2018.

3. Moncada, S., M. W. Radomski, and R. M. J. Palmer. 1988. Endotheliumderived relaxing factor. Identification as nitric oxide and role in the control of vascular tone and platelet function. Biochem. Pharmacol. 37:2495-2501.

4. Palmer, R. M. J., D. S. Ashton, and S. Moncada. 1988. Vascular endothelial cells synthesize nitric oxide from L-arginine. Nature (Lond.). 333:664-666.

5. Palmer, R. M. J., and S. Moncada. 1989. A novel citrulline-forming enzyme implicated in the formation of nitric oxide by vascular endothelial cells. Biochem. Biophys. Res. Commun. 158:348-352.

6. Ignarro, L. J. 1990. Biosynthesis and metabolism of endothelium-derived nitric oxide. Annu. Rev. Pharmacol. Toxicol. 30:535-560.

7. Rapoport, R. M., and F. Murad. 1988. Role of cyclic GMP in endotheliumdependent relaxation of vascular smooth muscle. In Relaxing and Contracting Factors. P. M. Vanhoutte, editor. Humana Press, Clifton, NJ. 219-239.

8. Ignarro, L. J. 1990. Nitric oxide. A novel signal transduction mechanism for transcellular communication. Hypertension (Dallas). 16:477-483.

9. Ishii, K., L. D. Gorsky, U. Förstermann, and F. Murad. 1989. Endothelium-derived relaxing factor (EDRF): the endogenous activator of soluble guanylate cyclase in various types of cells. J. Appl. Cardiol. 4:505-512.

10. Moncada, S., R. M. J. Palmer, and E. A. Higgs. 1991. Nitric oxide: physiology, pathophysiology, and pharmacology. Pharmacol. Rev. 43:109-142.

11. Andrews, H. E., K. R. Bruckdorfer, R. C. Dunn, and M. Jacobs. 1987. Low-density lipoproteins inhibit endothelium-dependent relaxation in rabbit aorta. Nature (Lond.). 327:237-239.

12. Jacobs, M., F. Plane, and K. R. Bruckdorfer. 1990. Native and oxidized low-density lipoproteins have different inhibitory effects on endothelium-derived relaxing factor in the rabbit aorta. Br. J. Pharmacol. 100:21-26.

13. Kugiyama, K., S. A. Kerns, J. D. Morrisett, R. Roberts, and P. D. Henry. 1990. Impairment of endothelium-dependent arterial relaxation by lysolecithin in modified low-density lipoproteins. Nature (Lond.). 344:160-162.

14. Takahashi, M., Y. Yui, H. Yasumoto, T. Aoyama, H. Morishita, R. Hattori, and C. Kawai. 1990. Lipoproteins are inhibitors of endothelium-dependent relaxation of rabbit aorta. Am. J. Physiol. 258 (Heart Circ. Physiol. 27):H1-H8.

15. Tomita, T., M. Ezaki, M. Miwa, K. Nakamura, and Y. Inoue. 1990. Rapid and reversible inhibition by low density lipoprotein of the endothelium-dependent relaxation to hemostatic substances in porcine coronary arteries. Heat and acid labile factors in low density lipoprotein mediate the inhibition. Circ. Res. 66:18-27.

16. Steinberg, D., S. Parthasarathy, T. E. Carew, J. C. Khoo, and J. L. Witzum. 1989. Beyond cholesterol. Modifications of low-density lipoprotein that increase its atherogenicity. N. Engl. J. Med. 320:915-924.

17. Verbeuren, T. J., F. H. Jordaens, L. L. Zonnekeyn, C. E. Van Hove, M.-C. Coene, and A. G. Herman. 1986. Effect of hypercholesterolemia on vascular reactivity in the rabbit. Circ. Res. 58:552-564.

18. Verbeuren, T. J., F. H. Jordaens, C. E. Van Hove, A.-E. Van Hoydonck, and A. G. Herman. 1990. Release and vascular activity of endothelium-derived relaxing factor in atherosclerotic rabbit aorta. Eur. J. Pharmacol. 191:173-184.

19. Bossaller, C., G. B. Habib, H. Yamamoto, C. Williams, S. Wells, and P. D. Henry. 1987. Impaired muscarinic endothelium-dependent relaxation and cyclic guanosine 5'-monophosphate formation in atherosclerotic human coronary artery and rabbit aorta. J. Clin. Invest. 79:170-174.

20. Förstermann, U., A. Mügge, U. Alheid, A. Haverich, and Jürgen C. Frölich. 1988. Selective attenuation of endothelium-mediated vasodilation in atherosclerotic human coronary arteries. Circ. Res. 62:185-190.

21. Creager, M. A., J. P. Cooke, M. E. Mendelsohn, S. J. Gallagher, S. M. Coleman, J. Loscalzo, and V. J. Dzau. 1990. Impaired vasodilation of forearm resistance vessels in hypercholesterolemic humans. J. Clin. Invest. 86:228-234.
22. Rossitch, E., Jr., E. Alexander III, P. Mcl. Black, and J. P. Cooke. 1991. L-Arginine normalizes endothelial function in cerebral vessels from hypercholesterolemic rabbits. J. Clin. Invest. 87:1295-1299.

23. Simon, B. C., L. D. Cunningham, and R. A. Cohen. 1990. Oxidized low density lipoproteins cause contraction and inhibit endothelium-dependent relaxation in the pig coronary artery. J. Clin. Invest. 86:75-79.

24. Tanner, F. C., G. Noll, C. M. Boulanger, and T. F. Lüscher. 1991. Oxidized low density lipoproteins inhibit relaxations of porcine coronary arteries. Role of scavenger receptor and endothelium-derived nitric oxide. Circulation. 83:2012-2020.

25. Galle, J., E. Bassenge, and R. Busse. 1990. Oxidized low density lipoproteins potentiate vasoconstrictions to various agonists by direct interaction with vascular smooth muscle. Circ. Res. 66:1287-1293.

26. Berliner, J. A., M. C. Territo, A. Sevanian, S. Ramin, J. A. Kim, B. Bamshad, M. Esterson, and A. M. Fogelman. 1990. Minimally modified low density lipoprotein stimulates monocyte endothelial interactions. J. Clin. Invest. 85:1260-1266

27. Ylä-Herttuala, S., W. Palinski, M. E. Rosenfeld, S. Parthasarathy, T. E. Carew, S. Butler, J. L. Witztum, and D. Steinberg. 1989. Evidence for the presence of oxidatively modified low density lipoprotein in atherosclerotic lesions of rabbit and man. J. Clin. Invest. 84:1086-1095.

28. Steinbrecher, U. P., H. Zhang and M. Lougheed. 1990. Role of oxidatively modified LDL in atherosclerosis. Free Radical Biology and Medicine. 9:155-168.

29. Rosenfeld, M. E., J. C. Khoo, E. Miller, S. Parthasarathy, W. Palinski, and J. L. Witztum. 1991. Macrophage-derived foam cells freshly isolated from rabbit atherosclerotic lesions degrade modified lipoproteins, promote oxidation of low density lipoproteins, and contain oxidation-specific lipid-protein adducts. J. Clin. Invest. 87:90-99.

30. Boulanger, C., H. Hendrickson, R. R. Lorenz, and P. M. Vanhoutte. 1989. Release of different relaxing factors by cultured porcine endothelial cells. Circ. Res. 64:1070-1078.

31. Reaven, E., X.-Y. Shi, and S. Azhar. 1990. Interaction of lipoproteins with isolated ovary plasma membranes. J. Biol. Chem. 265:19100-19111.

32. Steinbrecher, U. P., M. Lougheed, W.-C. Kwan, and M. Dirks. 1989. Recognition of oxidized low density lipoprotein by the scavenger receptor of macrophages results from derivatization of apoprotein $B$ by products of fatty acid peroxidation. J. Biol. Chem. 264:15216-15223.

33. Peterson, G. L. 1977. A simplification of the protein assay method of Lowry et al. which is more generally applicable. Anal. Biochem. 83:346-356.

34. Bligh, E. G., and W. J. Dyer. 1958. A rapid method of total lipid extraction and purification. Can. J. Biochem. Physiol. 37:911-917.

35. Leitman, D. C., V. L. Agnost, J. J. Tuan, J. W. Andresen, and F. Murad. 1987. Atrial natriuretic factor and sodium nitroprusside increase cyclic GMP in cultured rat lung fibroblasts by activating different forms of guanylate cyclase. Biochem. J. 244:69-74.

36. Förstermann, U., A. Mülsch, E. Böhme, and R. Busse. 1986. Stimulation of soluble guanylate cyclase by an acetylcholine-induced endothelium-derived factor from rabbit and canine arteries. Circ. Res. 58:531-538.

37. Ohkawa, H., N. Ohishi, and K. Yagi. 1979. Assay for lipid peroxides in animal tissues by thiobarbituric acid reaction. Anal. Biochem. 95:351-358.

38. DeLean, A., P. J. Munson, and D. Rodbard. 1978. Simultaneous analysis of families of sigmoidal curves: application to bioassay, radioligand assay, and physiological dose-response curves. Am. J. Physiol. 235:E97-E102.

39. Miller, D. M., and S. D. Aust. 1989. Studies of ascorbate-dependent, iron-catalyzed lipid peroxidation. Arch. Biochem. Biophys. 271:113-119.

40. Morel, D. W., J. R. Hessler, and G. M. Chisolm. 1983. Low density lipoprotein cytotoxicity induced by free radical peroxidation of lipid. J. Lipid Res. 24:1070-1076.

41. Esterbauer, H., G. Jurgens, O. Quehenberger, and E. Koller. 1987. Autoxidation of human low density lipoprotein: loss of polyunsaturated fatty acids and vitamin E and generation of aldehydes. J. Lipid Res. 28:495-509.

42. Sreeharan, N., R. L. Jayakody, M. P. J. Senaratne, A. B. R. Thomson, and C. T. Kappagoda. 1986. Endothelium-dependent relaxation and experimenta atherosclerosis in the rabbit aorta. Can. J. Physiol. Pharmacol. 64:1451-1453.

43. Guerra, R., Jr., A. F. A. Brotherton, P. J. Goodwin, C. R. Clark, M. L. Armstrong, and D. G. Harrison. 1989. Mechanisms of abnormal endotheliumdependent vascular relaxation in atherosclerosis: implications for altered autocrine and paracrine functions of EDRF. Blood Vessels. 26:300-314. 